\title{
Biznes cukrowniczy w Unii Europejskiej po zniesieniu kwot produkcyjnych - przypadek Polski
}

Henryk Wnorowski*

\section{Wstęp}

W niniejszym opracowaniu zakładamy, że głównym problemem i jednocześnie celem jest rozwój społeczno-gospodarczy, a w zasadzie potrzeba, pragnienie rozwoju, czy - jak kto woli - dążenie do rozwoju. Przyjmujemy także, że to dążenie jest powszechne, rozwój jest ambicją podmiotów na wszystkich poziomach agregacji - rozwijać się pragną gospodarki, a także podmioty gospodarcze i jednostki. W takiej sytuacji podmioty przemysłu cukrowniczego także dążą do rozwoju i są częścią postępu gospodarek, w których są zlokalizowane. W tym sensie biznes cukrowniczy przyczynia się do rozwoju tych gospodarek.

Kluczem do zrozumienia dynamiki procesu rozwoju ekonomicznego jest poznanie sensu działań człowieka. Arystoteles twierdził, że ludzie podejmuja działania celowe, bo taka jest natura działań ludzkich. Trudno wyobrazić sobie istoty ludzkie, które nie pragna doprowadzić do poprawy swoich warunków życia ${ }^{1}$. Twierdzenie to jest aksjomatem prakseologii, ekonomii i socjologii. Człowiek podejmuje działania po to, by zaspokoić przede wszystkim potrzeby niezbędne do życia, a następnie potrzeby wyższego rzędu. Zmierza do zmiany obecnego stanu rzeczy na nowy, który uznaje za bardziej zadawalający. Nieustannie dokonuje wyboru pomiędzy różnymi alternatywnymi celami, środkami oraz sposobami ich realizacji. Rezygnuje z jednych dóbr po to, by zdobyć inne, lepiej zaspokajające jego potrzeby ${ }^{2}$.

\footnotetext{
* Henryk Wnorowski - prof. nauk ekonomicznych, Uniwersytet w Białymstoku, Wydział Ekonomii i Zarządzania, Katedra Nauk o Przedsiębiorstwie, h.wnorowski@uwb.edu.pl.

${ }^{1}$ Arystoteles, Etyka nikomachejska, Wydawnictwo Naukowe PWN, Warszawa 2007.

${ }^{2}$ Człowiek opisywany przez Ludwiga von Misesa jest jednostka racjonalna. Wszyscy ludzie musza działać. Rezygnacja z podjęcia aktywności, zaniechanie bądź kierowanie się popędami jest także działaniem tak samo jak wypowiedzenie słów (np. w formie rozkazu czy prośby). Aby funkcjonować, ludzie z konieczności wartościuja, wybierają cele swych dążen i decydują się na konkretne sposoby
} 
To człowiek jest przyczyną/powodem wszelkiego porządku w świecie, ale niestety jest także przyczyną wszelkiego nieporządku. Można by to jeszcze skomentować wypowiedzią F. von Hayeka, wedle którego źródłem najpoważniejszych problemów społecznych jest to, że: istnieja skutki działań ludzkich, które nie sa rezultatem ludzkich zamierzeń ${ }^{3}$. Mnogość przykładów podobnego typu skłania do refleksji nad realnymi możliwościami człowieka próbującego w różnych sytuacjach oddziaływać na system, którego jest uczestnikiem, i który poniekąd jest jego autorstwa.

W tym miejscu autor formułuje hipotezę główną niniejszego artykułu: przedsiębiorczość okazuje się skutecznym orężem w walce o rozwój także w branży cukrowniczej. Historycznie rzecz ujmując, branża ta funkcjonowała w Unii Europejskiej z większymi lub mniejszymi sukcesami. Jeśli przyjmiemy, że biznes (cukrowniczy także) to przeprowadzanie aktywów od zastosowań niżej wycenianych do zastosowań wyżej wycenianych, to okaże się, że dynamika zmienności uwarunkowań zewnętrznych (systemu), w którym przychodziło funkcjonować przedsiębiorstwom, była bardzo duża. Celem artykułu jest wskazanie konsekwencji dla podmiotów funkcjonujących w biznesie cukrowniczym zmian wprowadzonych po 1 października 2017 r. na unijnym rynku cukru.

Branża cukrownicza w Unii Europejskiej, a tym samym w Polsce znalazła się dzisiaj (po raz kolejny) w nowej sytuacji. Od 1 października 2017 r. przeprowadzana jest reforma regulacji rynku cukru, której głównym elementem jest zniesienie kwot produkcji cukru oraz minimalnej ceny skupu buraków cukrowych. Zniesione wówczas regulacje funkcjonowały w ramach wspólnej polityki rolnej prawie 50 lat $^{4}$, pozwoliły więc na przyzwyczajenie się do nich wszystkim uczestnikom rynku cukru - producentom buraków cukrowych, producentom cukru, a także dystrybutorom. Próba nakreślenia sytuacji branży w nowej rzeczywistości wydaje się zatem jak najbardziej zasadna.

ich osiagnięcia. Zanim jednak jakiekolwiek działanie zostanie wykonane, człowiek musi przejść trzy poprzedzające etapy. Pierwszym jest zaistnienie dyskomfortu, czyli niepożądanego stanu rzeczy. Bez zaistnienia dyskomfortu żadne działanie nie zostanie podjęte, gdyż w warunkach petnego spetnienia jakakolwiek zmiana stanu mogłaby jedynie pogorszyć sytuacje podmiotu. (...) Aby działanie zostało wykonane, musi pojawić sie ponadto przekonanie, że celowe zachowanie jednostki może choć do pewnego stopnia zaspokoić potrzebe (zredukować dyskomfort). (...) Ostateczna decyzja, aby zadziałać, będzie wiazała się z kalkulacją, czy wysitek, jakim jest wstanie z hamaka, warty jest mniej niz nieprzyjemność zwiąana $z$ doświadczeniem uporczywego brzęczenia. Warto pamiętać o decydujacej roli przekonania jednostki o własnej sprawczości i zdolności człowieka do abstrakcyjnego myślenia - jeśli przyczynę brzęczenia stanowi nie komar, a przelatujacy samolot, nie wyklucza to możliwości działania, a jedynie powoduje, iż należy zastosować inne środki redukcji dyskomfortuw tym przypadku moga to być stopery ograniczajace hałas. - L. Papaj, Koncepcja człowieka w pracach Ludwiga von Milesa, Wydawnictwo Prohibita, Warszawa 2010, s. 31-34.

${ }^{3}$ F. von Hayek, Studies in Philosophy, „Politics and Economics”, Chicago 1967.

${ }^{4}$ Decyzję o zniesieniu systemu kwot podjęły wspólnie Parlament Europejski i kraje Unii Europejskiej w ramach przeprowadzonej w 2013 r. reformy WPR. 


\section{Wspólna polityka rolna i jej regulacje dotyczące produkcji cukru}

System kwot cukrowych ustanowiono w roku 1968 przepisami dotyczącymi wspólnej polityki rolnej (WPR). Jednocześnie zaczęto udzielać pomocy producentom - ustalono ceny na poziomie znacznie przewyższającym ceny na rynku światowym. Unijny rynek cukru opierał się na ścisłej kontroli podaży za pomocą ograniczeń produkcyjnych dla poszczególnych krajów (tzw. kwoty cukrowe) oraz restrykcyjnego systemu zarządzania nadwyżkami produkcji, czyli tzw. cukrem pozakwotowym. Na unijnym rynku funkcjonowała także minimalna cena skupu buraków cukrowych, jednak dotyczyła ona jedynie buraków cukrowych zakontraktowanych do produkcji cukru kwotowego.

Tabela 1. Wybrane elementy regulacji rynku cukru w Unii Europejskiej

\begin{tabular}{|l|c|}
\hline Regulacje rynkowe & Obowiązujące \\
\hline Kwoty produkcji & TAK \\
\hline Zagospodarowanie cukru pozakwotowego & TAK \\
\hline Cena referencyjna cukru & $404,40 \mathrm{EUR} / \mathrm{t}$ \\
\hline Cena minimalna skupu buraków cukrowych & $26,29 \mathrm{EUR} / \mathrm{t}$ \\
\hline Opłata produkcyjna & $12,00 \mathrm{EUR} / \mathrm{t}$ \\
\hline Monitorowanie cen cukru & TAK \\
\hline Import & $\begin{array}{c}\text { Prohibicyjne cła. Kontyngenty } \\
\text { preferencyjne: LDC, ACP, CXL, } \\
\text { kraje bałkańskie }\end{array}$ \\
\hline Eksport & \begin{tabular}{c} 
TAK \\
\hline Pozwolenia na wywóz i przywóz cukru
\end{tabular} \\
\hline Dopłaty do prywatnego magazynowania & TAK \\
\hline Związane z produkcją dopłaty do uprawy buraków cukrowych & TAK \\
\hline
\end{tabular}

Źródło: opracowanie IERiGŻ na podstawie danych Komisji Europejskiej, Rynek cukru - stan i perspektywy, kwiecień 2017.

Zgodnie z przepisami prawa UE poszczególne kraje członkowskie, wykorzystując odpowiednie instytucje (w Polsce była to Agencja Rynku Rolnego), monitorują kwotową i pozakwotową produkcję cukru. Monitorowanie odbywa się na podstawie przekazywanych przez producentów sprawozdań dotyczących produkcji, stanu zapasów i obrotu cukrem, a także wstępnego rocznego sprawozdania z wielkości produkcji cukru oraz sprawozdań z wielkości produkcji i powierzchni zasiewów zakontraktowanych buraków cukrowych. Producenci przekazują także do właściwych agencji informacje o średnich miesięcznych cenach sprzedaży cukru kwotowego i pozakwotowego oraz o odpowiadających im sprzedanych ilościach. 
Narzędzia regulacji rynku pokazane w tabeli 1 należy traktować jako istotne determinanty rynku światowego, a także rynku cukru w poszczególnych krajach członkowskich, w tym w Polsce. Sytuację na światowym rynku cukru obrazuje syntetyczny wskaźnik oceny koniunktury na podstawowych rynkach rolno-spożywczych. Indeks cen FAO dla cen cukru wyniósł w 2016 r., w odniesieniu do okresu bazowego 2002-2004, 256,0 pkt. i był o 65,3 pkt. wyższy od notowanego rok wcześniej.

Tabela 2. Ceny cukru białego na giełdzie w Londynie (USD/t)

\begin{tabular}{|l|l|l|l|l|l|l|}
\hline Lata/m-ce & 2012 & 2013 & 2014 & 2015 & 2016 & 2017 \\
\hline I & 629,1 & 500,4 & 419,8 & 393,5 & 420,0 & 538,1 \\
II & 635,5 & 501,1 & 453,3 & 384,5 & 386,7 & 548,3 \\
III & 646,5 & 524,7 & 466,7 & 366,3 & 439,6 & 508,2 \\
IV & 599,6 & 498,7 & 471,6 & 366,0 & 440,0 & 477,1 \\
V & 561,2 & 482,4 & 475,1 & 365,3 & 475,1 & 450,3 \\
VI & 587,4 & 489,6 & 472,7 & 352,7 & 528,2 & 407,6 \\
VII & 614,8 & 473,1 & 455,5 & 357,8 & 541,5 & 402,1 \\
VIII & 573,6 & 489,4 & 429,9 & 343,3 & 536,6 & 379,5 \\
IX & 561,9 & 483,7 & 423,3 & 351,2 & 571,4 & 370,9 \\
X & 564,1 & 499,6 & 425,9 & 387,8 & 595,0 & 373,0 \\
XI & 514,8 & 471,4 & 416,9 & 402,3 & 549,6 & 391,1 \\
XII & 515,2 & 445,2 & 392,7 & 410,5 & 504,2 & 377,6 \\
I-XII & 584,2 & 488,7 & 441,9 & 373,5 & 499,0 & 435,0 \\
\hline
\end{tabular}

Źródło: www.ers.usda.gov/data-products/surgar-and-sweeteners-yearbook-tables.aspx.

Średnia cena cukru białego w transakcjach na giełdzie w Londynie w $2016 \mathrm{r}$. wyniosła 499,0 USD/t i była wyższa o 33,6\% niż rok wcześniej. W październiku 2016 r. ceny cukru osiągnęły maksymalny poziom 595,0 USD/t i były o 73,3\% wyższe od cen najniższych, notowanych w sierpniu 2015 r. W listopadzie i grudniu 2016 r. nastąpiła znaczna korekta cen, ale od początku 2017 r. ceny zaczęły ponownie wzrastać w pierwszych dwóch miesiącach - do poziomu $550 \mathrm{USD} / \mathrm{t}$. Począwszy od marca, obserwujemy permanentny spadek cen cukru.

Ostatnia dekada to także okres wysokiej dynamiki cen cukru konfekcjonowanego na polskim rynku. Pomimo funkcjonującego systemu kwotowania produkcji całkowite wahania przekraczały nawet $100 \%$. W roku 2015, kiedy to ceny były najniższe, kształtowały się na poziomie średnio 1,71 zł/kg, zaś w roku 2011 (w którym mieliśmy do czynienia $\mathrm{z}$ najwyższym poziomem cen) - 3,96 zł/kg (patrz rysunek 1). 
Rysunek 1. Średnie ceny sprzedaży cukru konfekcjonowanego (w zł za 1 kg)

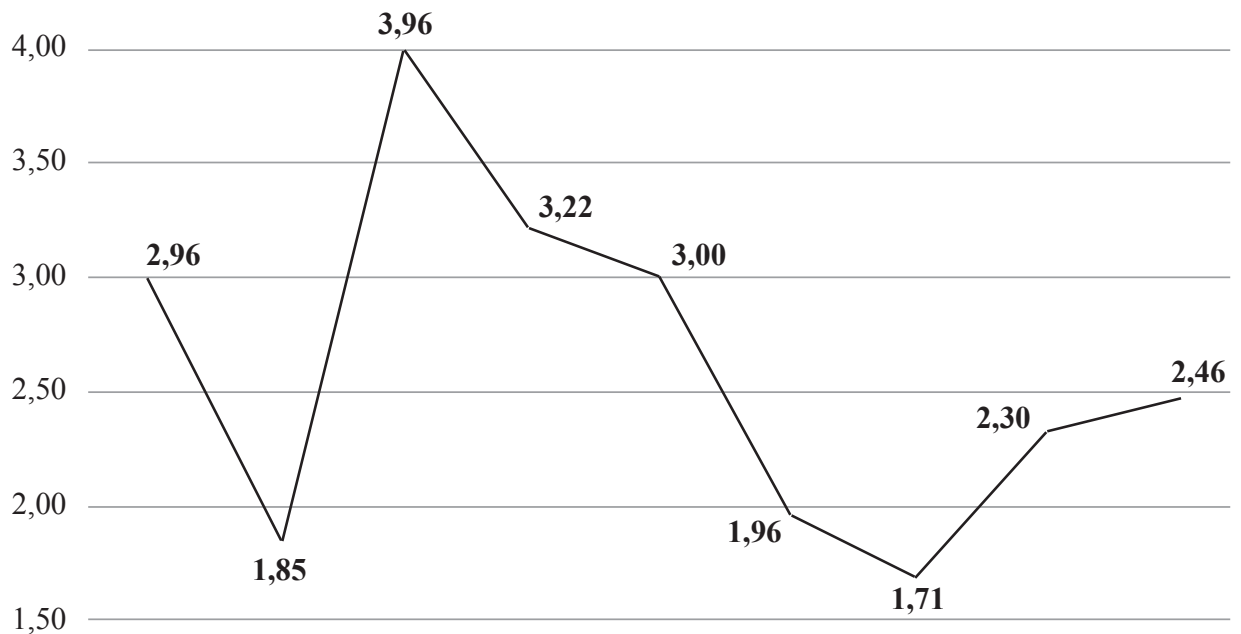

1,00

$\begin{array}{lllllllll}2009 & 2010 & 2011 & 2012 & 2013 & 2014 & 2015 & 2016 & 2017\end{array}$

Źródło: Ptak A., Polski cukier śpi na bombie, ,Rzeczpospolita”, 18.05.2017.

Rysunek 1 pokazuje, na jakim poziomie kształtowały się średnie ceny cukru konfekcjonowanego w Polsce w latach 2009-2017.

\section{Polska jako producent i konsument cukru na tle Unii Europejskiej}

Przystąpienie Polski do Unii Europejskiej zmieniło uwarunkowania prawne i gospodarcze związane z funkcjonowaniem branży cukrowniczej. Od tego moment $\mathrm{w}$ polskim cukrownictwie zaczęły zachodzić głębokie zmiany strukturalne - znacząco zmniejszyły się liczba cukrowni oraz zatrudnienie w przemyśle cukrowniczym, co znalazło odzwierciedlenie w istotnym wzroście jego wydajności i poprawie konkurencyjności. W 2006 r. przeprowadzono reformę sektora cukru, której głównym elementem była redukcja kwot produkcyjnych przyznawanych państwom członkowskim, rozdzielonych pomiędzy producentów cukru.

Na skutek tej reformy i wprowadzenia limitów na wywóz w następstwie orzeczenia WTO wielkość produkcji cukru w Unii Europejskiej spadła poniżej poziomu wewnętrznego zapotrzebowania na cukier. Wiele państw członkowskich ograniczyło produkcję, a pięć z nich w ogóle jej zaprzestało. W efekcie w Polsce buraki 
cukrowe są dzisiaj przetwarzane w 18 cukrowniach, które funkcjonują w strukturach czterech koncernów cukrowniczych. Struktura podmiotowa krajowego sektora cukrowniczego jest silnie skoncentrowana, a ponad $60 \%$ udziału w rynku mają trzy niemieckie koncerny cukrownicze. Czwartym producentem cukru w Polsce jest Krajowa Spółka Cukrowa (Polski Cukier) - jedyny podmiot z polskim kapitałem. Pod względem wielkości produkcji KSC jest największym producen-tem w kraju i ósmym w Unii Europejskiej.

Rysunek 2. Najwięksi producenci cukru w Polsce i UE w roku obrotowym 2016/2017 (w\%)

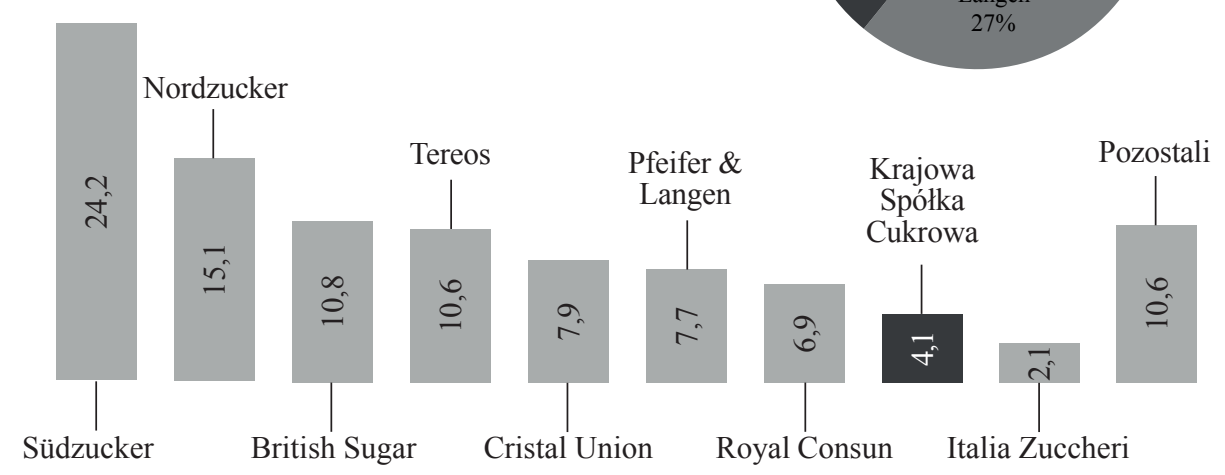

Źródło: Ptak A., Słodko-gorzka zagadka, „Rzeczpospolita”, 18.05.2017; Ptak A., Polski cukier śpi na bombie, ,Rzeczpospolita”, 18.05.2017.

Mimo wyraźnego zwiększenia wydajności polskiego przemysłu cukrowniczego jest ona nadal niższa niż wydajność pozostałych największych producentów cukru w UE. Zgodnie z danymi Instytutu Ekonomiki Rolnictwa i Gospodarki Żywnościowej przeciętna produkcja cukru na jedną cukrownię w Niemczech w latach 2013-2016 wynosiła 187 tys. t, a na jednego zatrudnionego - 797 t. W Polsce było to odpowiednio 103 tys. t oraz $564 t^{5}$.

\footnotetext{
${ }^{5}$ Można jednak oczekiwać, że zwiększenie konkurencji po deregulacji unijnego rynku cukru będzie sprzyjać dalszemu wzrostowi wydajności w polskim cukrownictwie. Podstawą takiej oceny jest wzrost inwestycji w polskiej branży cukrowniczej w pierwszej połowie $2017 \mathrm{r}$. o $25,8 \% \mathrm{r} / \mathrm{r}$, co jest jednocześnie najwyższą dynamiką od 2010 r. Co więcej od 2016 r. dynamika inwestycji w polskim cukrownictwie jest dodatnia, a trend wzrostowy się utrzymuje. Świadczy to o tym, że branża w ostatnich kwartałach przygotowywała się do deregulacji unijnego rynku cukru - „Credit Agricole" AGRO, Kwartalnik Agrobiznesu, Jesień 2017.
} 
Tabela 3. Produkcja cukru w Unii Europejskiej (w tys. ton)

\begin{tabular}{|l|r|r|r|}
\hline Wyszczególnienie & $2014 / 2015$ & $2015 / 2016$ & $2016 / 2017$ \\
\hline Austria & 391,8 & 411,2 & 409,0 \\
Belgia i Luksemburg & 846,6 & 749,5 & 682,6 \\
Chorwacja & 359,9 & 119,6 & 192,9 \\
Czechy & 596,4 & 455,9 & 541,5 \\
Dania & 476,5 & 310,5 & 415,0 \\
Finlandia & 138,2 & 120,2 & 65,6 \\
Francja & 4576,5 & 4034,0 & 4578,7 \\
Francja (dep. zamorskie) & 495,4 & 563,0 & 280,0 \\
Grecja & 193,5 & 150,7 & 37,3 \\
Hiszpania & 606,5 & 562,6 & 537,8 \\
Litwa & 183,3 & 128,0 & 131,3 \\
Holandia & 1093,9 & 765,4 & 925,1 \\
Niemcy & 4494,7 & 2942,3 & 3758,4 \\
Polska & 1983,0 & 1422,8 & 2100,0 \\
Portugalia (Azory) & 0,0 & 0,4 & 1,8 \\
Rumunia & 219,0 & 119,1 & 118,3 \\
Słowacja & 206,5 & 232,4 & 200,8 \\
Szwecja & 382,4 & 257,7 & 323,4 \\
Węgry & 129,9 & 128,8 & 122,3 \\
Wielka Brytania & 1446,5 & 977,9 & 937,1 \\
Włochy & 692,6 & 480,4 & 303,4 \\
\hline Razem UE-28 & 19513,1 & 14932,4 & 16662,6 \\
\hline
\end{tabular}

Źródło: opracowanie IERiGŻ na podstawie danych Komisji Europejskiej, Rynek cukru - stan i perspektywy, kwiecień 2017.

Według danych Stowarzyszenia Techników Cukrowników powierzchnia uprawy buraków cukrowych w Polsce w 2016 r. wyniosła 203,1 tys. ha, plony 65,5 t/ha, a zbiory $-13,5 \mathrm{mln}$ t. Powodem wzrostu areału była większa kontraktacja surowca przez przemysł cukrowniczy, który rozpoczął przygotowania do zmian w systemie regulacji rynkowych, głównie do likwidacji kwot produkcyjnych. Ponadto koncerny cukrownicze chciały wykorzystać poprawę koniunktury na krajowym i światowym rynku cukru, której wyrazem był wzrost cen. Zwiększenie plonów było wynikiem korzystnych warunków pogodowych w okresie wegetacji zbiorów oraz poprawy efektywności uprawy. W rejonach plantacyjnych poszczególnych cukrowni plony były bardzo zróżnicowane (57,6-78,5 t/ha). Było to spowodowane różnymi warunkami glebowymi, pogodowymi (głównie rozkładem i intensywnością opadów) oraz zróżnicowaną intensywnością technologii uprawy. Należy jednak podkreślić, że w rejonach plantacyjnych charakteryzujących się wysokimi plonami odnotowano mniejszą zawartość cukru w korzeniach (tzw. polaryzację) niż w rejonach, w których uzyskano mniejsze plony ${ }^{6}$.

${ }^{6}$ P. Szajner, Produkcja buraków cukrowych [w:] P. Szajner (red.), Rynek cukru, stan i perspektywy, kwiecień 2017, Instytut Ekonomiki Rolnictwa i Gospodarki Żywnościowej - Państwowy Instytut Badawczy, Warszawa 2017. 
Rysunek 3. Wskaźniki produkcyjne buraka cukrowego w Polsce
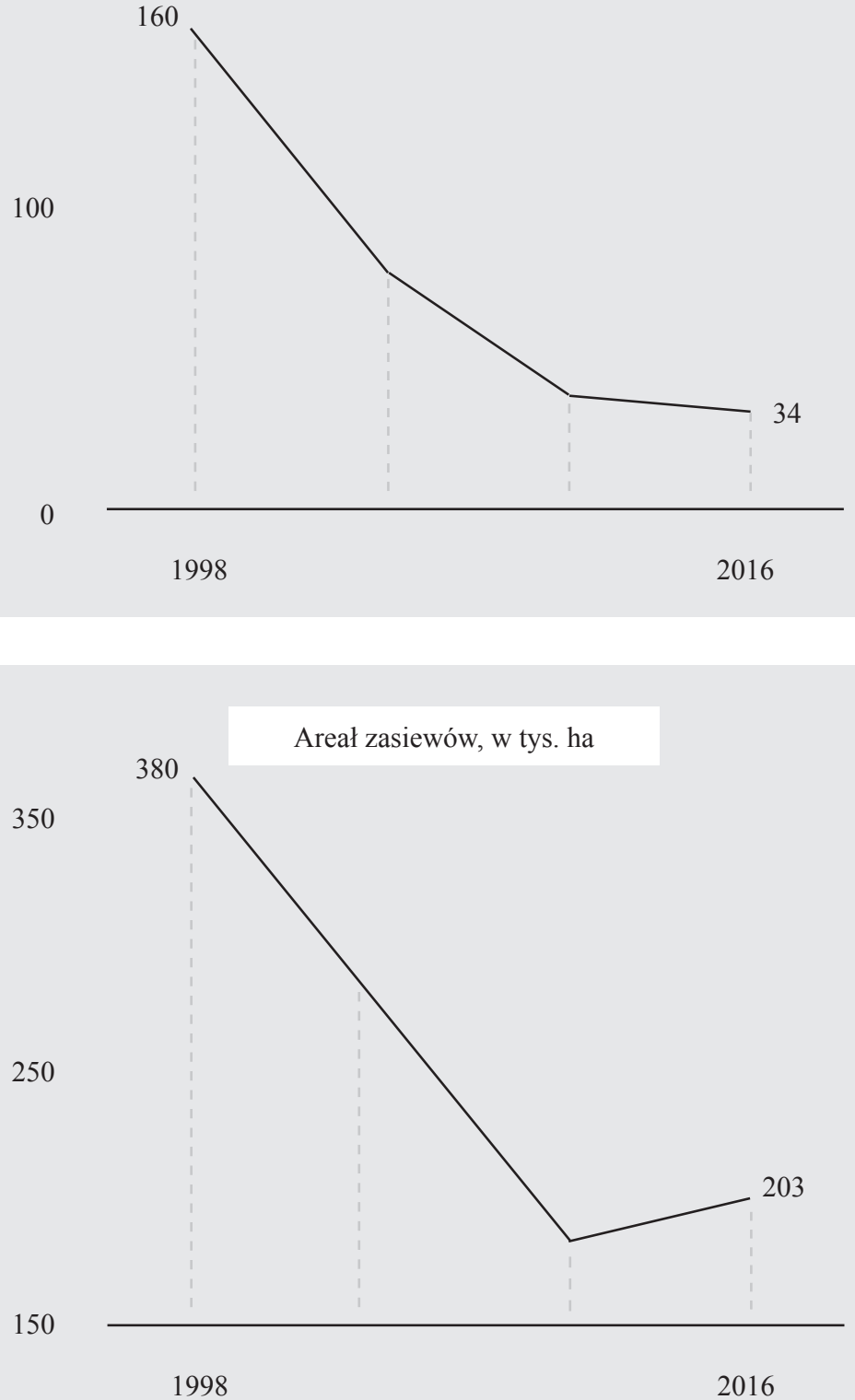

Źródło: Ptak A., Słodko-gorzka zagadka, Rzeczpospolita, 18.05.2017; Ptak A., Polski cukier śpi na bombie, „Rzeczpospolita”, 18.05.2017. 


\begin{tabular}{|c|c|c|c|c|c|c|}
\hline 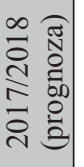 & 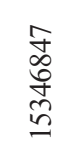 & $\begin{array}{l}\hat{\sigma} \\
\hat{\sigma}\end{array}$ & $\begin{array}{l}8 \\
\text { a } \\
\frac{a}{2} \\
\text { a }\end{array}$ & $\begin{array}{l}8 \\
\infty \\
\infty \\
N \\
\text { Tे } \\
m\end{array}$ & 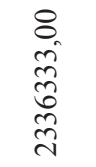 & $\frac{m}{=}$ \\
\hline 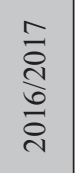 & 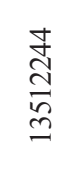 & $\begin{array}{l}n \\
\hat{n} \\
\delta\end{array}$ & $\begin{array}{l}8 \\
\dot{8} \\
\frac{0}{0} \\
\stackrel{1}{1}\end{array}$ & 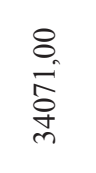 & $\begin{array}{l}\infty \\
\stackrel{\infty}{f} \\
\underset{f}{+} \\
\stackrel{\nu}{\infty}\end{array}$ & $\begin{array}{l}\stackrel{2}{=} \\
\stackrel{2}{n}\end{array}$ \\
\hline $\begin{array}{l}\frac{0}{0} \\
\frac{1}{2} \\
\frac{n}{0} \\
0\end{array}$ & $\begin{array}{l}\infty \\
\infty \\
n \\
\tilde{n} \\
\tilde{n} \\
\tilde{n}\end{array}$ & $\begin{array}{l}0 \\
\dot{f} \\
n\end{array}$ & 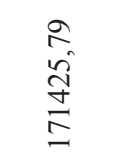 & $\begin{array}{l}8 \\
\text { in } \\
\text { in } \\
\text { m }\end{array}$ & 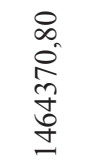 & $\begin{array}{l}\hat{\sigma} \\
\check{I}\end{array}$ \\
\hline $\begin{array}{l}\frac{n}{0} \\
\stackrel{\text { ch }}{J} \\
\text { o }\end{array}$ & 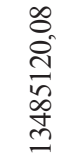 & $\begin{array}{l}\stackrel{0}{1} \\
\infty \\
\infty\end{array}$ & 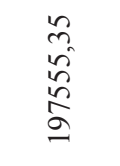 & $\begin{array}{l}8 \\
\text { ñ } \\
\hat{0} \\
n \\
m\end{array}$ & $\begin{array}{l}\text { to } \\
\infty \\
\infty \\
0 \\
0 \\
0 \\
0\end{array}$ & $\begin{array}{l}\infty \\
\circ \\
\end{array}$ \\
\hline 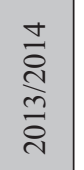 & $\begin{array}{l}\vec{n} \\
\stackrel{\Xi}{\Xi} \\
=\end{array}$ & $\frac{0}{8}$ & $\begin{array}{l}8 \\
\infty \\
\hat{n} \\
\infty \\
\infty \\
\infty\end{array}$ & $\begin{array}{l}8 \\
8 \\
8 \\
\infty \\
n \\
n\end{array}$ & $\begin{array}{l}m \\
m \\
\infty \\
\infty \\
\infty \\
\infty \\
\Sigma\end{array}$ & $\begin{array}{l}\text { ర్ } \\
\text { I }\end{array}$ \\
\hline $\begin{array}{l}\frac{m}{0} \\
\stackrel{n}{1} \\
\text { co } \\
0\end{array}$ & 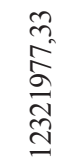 & $\frac{\mathbb{\sigma}}{\sigma 0}$ & $\begin{array}{l}8 \\
\frac{1}{m} \\
\text { a }\end{array}$ & $\begin{array}{l}8 \\
i \\
\infty \\
\infty \\
n \\
m\end{array}$ & $\begin{array}{l}8 \\
0 \\
\text { ते } \\
\tilde{0} \\
\infty \\
0\end{array}$ & $\stackrel{ }{I}$ \\
\hline 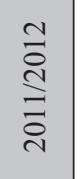 & $\begin{array}{l}\hat{0} \\
\text { तै } \\
\text { है } \\
=\end{array}$ & $\begin{array}{l}\text { రु } \\
\text { on }\end{array}$ & 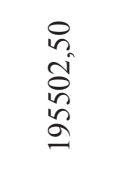 & $\begin{array}{l}8 \\
8 \\
8 \\
\infty \\
i n \\
m\end{array}$ & $\begin{array}{l}\frac{m}{1} \\
\stackrel{n}{0} \\
\infty \\
\infty \\
\infty\end{array}$ & $\begin{array}{l}\infty \\
\stackrel{2}{\Xi}\end{array}$ \\
\hline 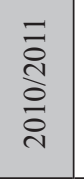 & $\begin{array}{l}\text { ते } \\
\frac{0}{5} \\
\frac{1}{2} \\
\sigma\end{array}$ & $\frac{a}{i n}$ & \begin{tabular}{l}
$\tilde{n}$ \\
$\stackrel{2}{a}$ \\
\multirow{2}{a}{}
\end{tabular} & $\begin{array}{l}8 \\
0 \\
0 \\
\infty \\
\infty \\
\infty\end{array}$ & 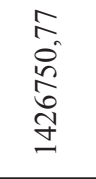 & $\vec{J}_{0}$ \\
\hline 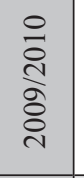 & 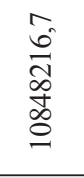 & $\begin{array}{l}\infty \\
\hat{\sigma} \\
\emptyset^{\circ}\end{array}$ & $\begin{array}{l}\tilde{\sigma} \\
\hat{\sigma} \\
\sigma \\
\sigma\end{array}$ & $\begin{array}{l}8 \\
\stackrel{8}{\exists} \\
\dot{y}\end{array}$ & $\begin{array}{l}\text { مे } \\
\text { ते } \\
\delta \\
\delta \\
0\end{array}$ & 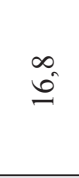 \\
\hline 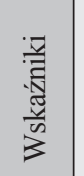 & 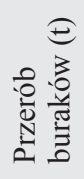 & 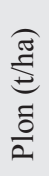 & 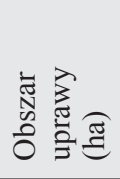 & 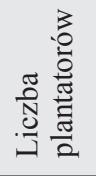 & 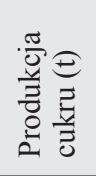 & $\begin{array}{l}\frac{\pi}{2} \\
\stackrel{\mathbb{N}}{\mathbb{E}} \\
\frac{\mathbb{E}}{0}\end{array}$ \\
\hline
\end{tabular}


Według danych przekazywanych Agencji Rynku Rolnego przez producentów w sezonie 2016/2017, czyli ostatnim roku obrotowym obowiązywania kwot produkcyjnych, produkcja cukru wyniosła 1959,4 tys. t i była wyższa o ponad $30 \%$ niż w sezonie poprzednim. Głównym powodem wzrostu produkcji były większe plony buraka cukrowego, a tym samym wyższa podaż surowca.

\section{Liberalizacja rynku cukru w UE}

Wprowadzona 1 października 2017 r. reforma regulacji rynku cukru oznacza przede wszystkim likwidację kwot produkcji cukru oraz minimalnej ceny skupu buraków cukrowych. Oznacza jednak także pewne zmiany regulacji handlu zagranicznego, co ma istotne znaczenie w świetle dotychczasowej struktury handlu zagranicznego tym produktem (patrz rysunki 4 i 5). Rynek Unii Europejskiej nadal będzie chroniony wysokimi cłami, ale możliwy będzie import w ramach preferencyjnych kontyngentów. Należy wziąć pod uwagę fakt, że UE coraz częściej decyduje się na podpisywanie umów handlowych z krajami, dla których obniża się lub całkowicie eliminuje cło na przywóz cukru na rynek unijny w zamian za ustępstwa, co w dłuższej perspektywie może być poważnym zagrożeniem dla całej branży cukrowniczej w Europie. UE otworzyła swoje granice dla krajów Afryki, Karaibów i Pacyfiku (ACP), najsłabiej rozwiniętych krajów świata (LDC) oraz innych, stosując zerowe stawki celne. Umożliwia także import cukru z Brazylii, Kuby, Australii i Indii w obniżonej stawce celnej w ramach kontyngentów taryfowych? ${ }^{7}$.

Rysunek 4. Struktura geograficzna eksportu i importu w UE

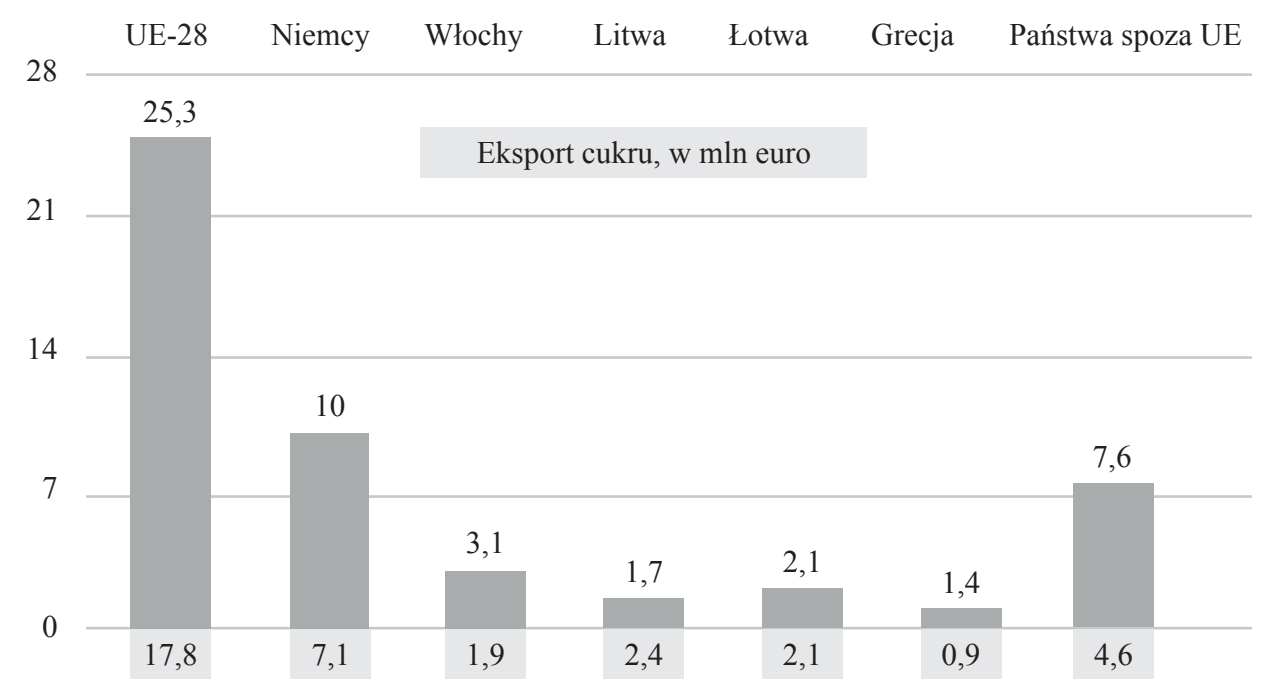

\footnotetext{
${ }^{7}$ M. Gawryszczak, Zniesienie kwot cukrowych, „Gazeta cukrownicza”, grudzień 2017, Związek Producentów Cukru w Polsce.
} 


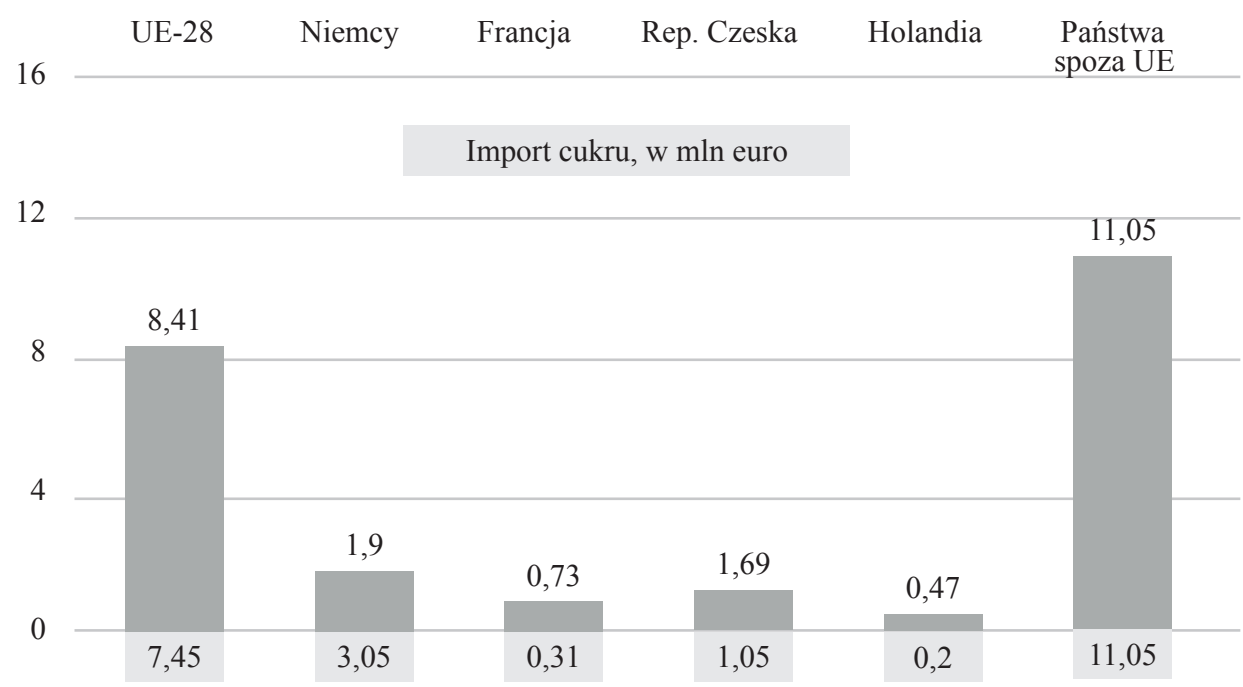

Źródło: Ptak A., Słodko-gorzka zagadka, Rzeczpospolita, 18.05.2017; Ptak A., Polski cukier śpi na bombie, ,Rzeczpospolita”, 18.05.2017.

Rysunek 5. Polska jako eksporter i importer cukru (w warunkach kwotowania)

\section{Eksport cukru z Polski}

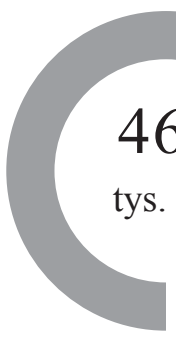

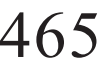

tys. ton w tym

do UE

285 tys. ton

Import cukru do Polski

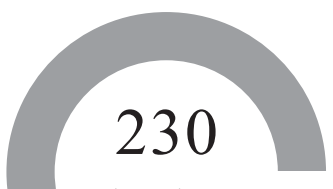

tys. ton

w tym

86 tys. ton

z UE

Źródło: Ptak A., Słodko-gorzka zagadka, Rzeczpospolita, 18.05.2017.

Komisja Europejska zapowiada, że w razie nieoczekiwanych zakłóceń funkcjonowania rynku producenci mogą liczyć na pomoc ze strony Unii Europejskiej w formie różnych środków dostępnych w ramach wspólnej polityki rolnej. Chodzi m.in. o cła przywozowe, które będzie można stosować tam, gdzie nie obowiązują preferencyjne umowy handlowe, oraz możliwość prywatnego przechowywania lub stosowania przez Komisję środków nadzwyczajnych w przypadku poważnego kryzysu związanego z gwałtownym wzrostem lub spadkiem cen rynkowych ${ }^{8}$.

\footnotetext{
${ }^{8}$ Tamże.
} 


\section{Podsumowanie}

Konsekwencje deregulacji unijnego rynku cukru w odniesieniu do funkcjonowania przedsiębiorstw prowadzących działalność w tej branży są istotne. Zwiększyła się podatność rynku unijnego na światowe szoki popytowo-podażowe, a to będzie prowadziło do wzrostu korelacji cen cukru w Unii Europejskiej ze światowymi cenami cukru. Wydaje się, że główny obszar, w którym będziemy mieli do czynienia $\mathrm{z}$ konsekwencjami deregulacji, to zwiększanie zmienności poziomu cen cukru. W konsekwencji przeprowadzanie aktywów do zastosowań wyżej wycenianych w tej branży będzie bardziej nieprzewidywalne, a więc będzie oznaczało utrudnienia w prowadzeniu biznesu.

Zniesienie ograniczeń produkcyjnych będzie również sprzyjało rosnącej geograficznej koncentracji produkcji w krajach, w których występują przewagi komparatywne w produkcji buraków cukrowych, związane m.in. z korzystniejszymi warunkami glebowo-klimatycznymi oraz niższymi kosztami produkcji ${ }^{9}$. Najprawdopodobniej w ciągu kilku lat znikną kolejne kraje członkowskie Unii Europejskiej (z zestawienia zawartego w tabeli 4) figurujące dotychczas jako producenci cukru $\mathrm{z}$ buraka cukrowego.

Postępujący od marca 2017 r. spadek cen cukru na rynku światowym wynika nie tylko $\mathrm{z}$ opisanych konsekwencji zmian regulacji unijnych, ale także $\mathrm{z}$ szacunków wskazujących na wyraźny wzrost produkcji cukru w sezonie 2017/2018. Faktyczny wzrost, jaki właśnie miał miejsce, doprowadzi najpierw do zahamowania utrzymującego się od dwóch sezonów spadku światowych zapasów cukru, a następnie do jego wzrostu.

\section{Bibliografia}

Arystoteles, Etyka nikomachejska, Wydawnictwo Naukowe PWN, Warszawa 2007. „Credit Agricole” AGRO, „Kwartalnik Agrobiznesu”, Jesień 2017.

Gawryszczak M., Zniesienie kwot cukrowych, „Gazeta Cukrownicza”, grudzień 2017, Związek Producentów Cukru w Polsce.

Papaj L. (2010), Koncepcja człowieka w pracach Ludwiga von Milesa, Wydawnictwo Prohibita, Warszawa.

Ptak A., Polski cukier śpi na bombie, „Rzeczpospolita”, 18.05.2017.

Ptak A., Stodko-gorzka zagadka, „Rzeczpospolita”, 18.05.2017.

Szajner P. (red.) (2017), Rynek cukru, stan i perspektywy, kwiecień 2017, Instytut Ekonomiki Rolnictwa i Gospodarki Żywnościowej - Państwowy Instytut Badawczy, Warszawa.

\footnotetext{
${ }^{9}$ Bardzo podobne zjawisko można było zaobserwować na unijnym rynku mleka po tym, jak w kwietniu 2015 r. w Unii Europejskiej zniesione zostały kwoty mleczne.
} 
Hayek F. von (1967), Studies in Philosophy, „Politics and Economics”, Chicago. Wnorowski H. (2014), Assorted methods of making of pricing decisions in an enterprise, „Studies in Logic, Grammar and Rethoric" Under the Auspices of the Polish Association for Logic and Philosophy of Science, „Mechanisms and Methods of Decision Making" (red. E. Roszkowska), University of Bialystok, nr 37(50).

\section{Streszczenie}

Produkcja cukru jest ważną częścią nie tylko polskiego sektora rolno-spożywczego, ale także całej UE. Funkcjonujące w tej branży przedsiębiorstwa mają własne mikroekonomiczne cele, a także przyczyniają się do rozwoju gospodarek, w których są zlokalizowane. Wyniki przez nie osiągane w dużym stopniu zależą od uwarunkowań ekonomicznych, ale także regulacyjnych. 1 października 2017 r. została przeprowadzona bardzo istotna zmiana regulacyjna, a mianowicie reforma regulacji rynku cukru, której głównym elementem jest zniesienie kwot produkcyjnych cukru oraz minimalnej ceny skupu buraków cukrowych. Stąd autor niniejszego artykułu, biorąc pod uwagę fakt, że zniesione regulacje funkcjonowały w ramach wspólnej polityki rolnej prawie 50 lat, stara się odpowiedzieć na pytanie o konsekwencje tych zmian dla biznesu cukrowniczego w UE.

Bez wątpienia nowa rzeczywistość, w jakiej znaleźli się unijni oraz polscy producenci cukru, a także plantatorzy buraka cukrowego, będzie dla nich wymagająca i będzie oznaczała dużą dynamikę zjawisk rynkowych. Zwiększy się podatność rynku unijnego na światowe szoki popytowo-podażowe. Wydaje się, że główny obszar, w którym będziemy mieli do czynienia z konsekwencjami deregulacji, to zwiększanie zmienności poziomu cen cukru. W konsekwencji prowadzenie biznesu w tej branży będzie bardziej nieprzewidywalne.

Słowa kluczowe: biznes cukrowniczy, wspólna polityka rolna, cukier, światowy rynek cukru, kwoty produkcyjne

\section{Summary}

Sugar business in the European Union after the elimination of production quotas - the case of Poland

Sugar production is an important part of the agri-food sector in the European Union in general, and Poland in particular. Companies operating in this industry im-plement their own microeconomic goals and contribute to the development of the economies in which they are located. The results they achieved depend, to a large extent, on both economic and regulatory conditions. On 1 October 2017, 
a very important regulatory change was carried out, namely the reform of the sugar market regulation, the main element of which is the abolition of sugar production quotas and the minimum purchase price of sugar beet. Therefore, the author of this article, taking into account the fact that the regulations abolished on that date had functioned within the framework of the Common Agricultural Policy for almost fifty years, tries to answer the question about the consequences of the changes for the sugar industry in the EU. Without any doubt, the new reality in which EU and Polish sugar producers, as well as the sugar beet growers, have found themselves, will be demanding and will result in higher dynamics of the market mechanism. The vulnerability of the EU market to global demand-supply shocks will increase. It seems that an increase in the volatility of sugar prices will be one of the main consequences of deregulation. As a result, running a business in this industry will be more unpredictable.

Keywords: sugar business, common agricultural policy, sugar, global sugar market, production quotas

JEL: F15, F62, Q17 